УДК 343.98

DOI https://doi.org/10.32837/apdp.v0i86.2424

А. Д. Марушев

\title{
ПРИНЦИПИ ЗАСТОСУВАННЯ СПЕЦІАЛЬНИХ ЗНАНЬ У КРИМІНАЛЬНОМУ ПРОВАДЖЕННІ
}

Актуальність теми. Удосконалення інституту спеціальних знань на досудовому слідстві $€$ важливою складовою частиною судово-правової реформи в Україні. Зростання можливостей упровадження новітніх досягнень науки і техніки у процес розслідування кримінальних правопорушень, необхідність більш раціонально організувати процес доказування зумовлюють значну увагу вчених до проблем використання спеціальних знань на досудовому слідстві. Однак питання правового забезпечення використання спеціальних знань на досудовому слідстві не тільки не вичерпані, але і потребують подальшого вдосконалення і розроблення. Зокрема, теоретичного аналізу потребують питання правової регламентації спеціальних знань, принципи застосування спеціальних знань у кримінальному судочинстві. Немає єдиної думки щодо процесуальної регламентації, змісту та класифікації форм спеціальних знань тощо.

Ступінь наукової розробки. Загальні організаційно-тактичні аспекти застосування спеціальних знань у кримінальному провадженні розглядались у наукових працях із кримінального процесу, криміналістики і теорії судової експертизи такими українськими вченими, як: Л.Ю. Ароцкер, О.О. Бондаренко, А.Ф. Волобуєв, В.Г. Гончаренко, І.В. Гора, Г.Л. Грановський, Ю.М. Грошевий, М.В. Даньшин, А.В. Журавель, А.В. Іщенко, Н.С. Карпов, Н.І. Клименко, І.І. Когутич, В.А. Колесник, В.П. Колмаков, В.О. Коновалова, В.К. Лисиченко, О.М. Моїсєєв, Г.М. Надгорний, І.В. Постіка, М.В. Салтевський, Е.Б. Сімакова-Єфремян, Р.Л. Степанюк, І.Я. Фрідман, В.В. Циркаль, К.О. Чаплинський, В.Ю. Шепітько, В.М. Шерстюк та ін.

Окремі проблеми використання спеціальних знань під час розслідування кримінальних правопорушень були предметом дисертаційних досліджень Є.Є. Демидової («Тактика допиту обізнаних осіб». Харків, 2013 р.), В.І. Дячука («Використання спеціальних знань при розслідуванні дорожньо-транспортних пригод». Київ, 2010 р.), А.В. Мировської («Використання спеціальних знань при розслідуванні фальшивомонетництва». Ірпінь, 2012 р.), П.Ю. Кравчука («Використання спеціальних знань під час розслідування грабежів і розбоїв». Ірпінь, 2015 р.), К.А. Садчикова ( Використання спеціальних знань на стадії досудового розслідування (процесуальний аспект)». Одеса, 2017 р.), В.О Яремчук («Залучення спеціаліста до проведення слідчих дій (організація і тактика)». Харків, 2014 р.) та інших.

Мета статті - визначити загальні засади / принципи використання спеціальних знань у процесі розслідування злочинів; визначити й охарактеризувати правові й організаційні засади використання спеціальних знань під час розслідування злочинів. 
Виклад основного матеріалу. Аналіз слідчої та судової практики свідчить про те, що правові проблеми використання знань спеціалістів останніми роками широко обговорюються серед науковців. Проте зазвичай вивчалися питання, пов'язані з удосконаленням законодавства про експертизу, застосуванням знань спеціалістів у процесі проведення окремих слідчих (розшукових) дій тощо. Незважаючи на те, що знання спеціалістів використовують у різних формах, уважаємо доцільним сформулювати єдині умови правомірності використання спеціальних знань, що випливають із законодавства, вимоги, що висуваються до них, до їхніх дій, зумовлені загальним призначенням спеціалістів своїми спеціальними знаннями з ініціативи органів слідства і суду надавати їм допомогу у встановленні об'єктивної дійсності у провадженні. Значення цих положень полягає в тому, що вони дають правильні орієнтири, допомагають розібратися у складних випадках використання спеціальних знань, що виникають на практиці, сприяють формуванню в законодавстві більш змістовних норм, за наявності яких відпадає потреба дублювати ті самі положення стосовно кожного спеціаліста. Крім того, наукова розробка цих положень дозволяє з єдиних вихідних позицій більш повно дослідити питання використання спеціальних знань у тій чи іншій конкретній формі.

Інституту використання спеціальних знань у сучасній науці кримінально-процесуального права та криміналістики приділяється значна увага, як і підставам та умовам застосування знань із неправових сфер у процесі розслідуванні злочинів. На жаль, у чинному кримінальному процесуальному законодавстві теж немає чіткого їх розуміння, що призводить до виникнення численних питань і складних ситуацій, з якими важко впоратися. У науковій літературі є чимало інтерпретацій визначення поняття «спеціальні знання». На наш погляд, заслуговує на увагу визначення В.М. Махова, який зазначає: «Спеціальні знання - це знання, притаманні різним видам професійної діяльності, за винятком знань, які є професійними для слідчого і судді, що використовуються під час розслідування злочинів і розгляду кримінальних справ у суді з метою сприяння встановленню істини у справі у випадку і порядку, встановлених кримінально-процесуальним законодавством» [6, с. 46]. Отже, у загальному вигляді можна визначити, що спеціальні знання, які застосовуються у процесі розслідування злочинів, - це система знань, навичок і вмінь у галузі науки, техніки, мистецтва або ремесла, які застосовуються суб’єктами розслідування у кримінальному провадженні під час виконання процесуальних, слідчих (розшукових) і організаційних дій, у різних формах їх вираження.

У юридичній літературі під правовими принципами розуміється сукупність ідей, на яких базуються численні елементи правової системи [1, с. 96]. Що стосується діяльності з виявлення, розкриття й розслідування злочинів, на думку П.Ф. Герасимова, загальними положеннями є такі: найсуворіше дотримання законності; плановість та швидкість; активність і широке застосування у процесі розслідування науково-технічних засобів; обов'язкове залучення громадськості (правильне ставлення до оцінки доказів); знання кожним учасником взаємодії повноважень і форм діяльності органів слідства й дізнання [2, с. 7-8].

На наш погляд, принципи використання спеціальних знань визначеними суб'єктами кримінального провадження збігаються передусім із нормами 
та принципами кримінального процесуального законодавства, являють собою найважливіші й визначальні правові положення, на яких грунтується кримінальний процес. Необхідно зазначити, що найбільш детально у криміналістичній літературі розглянуто принципи взаємодії слідчого з органами, що здійснюють оперативно-розшукову діяльність, та з експертами й експертно-криміналістичними підрозділами [7, с. 6-7]. Так, В.Ю. Шепітько зазначає, що взаємодія в діяльності з розкриття і розслідування злочинів повинна мати конкретний характер, грунтуватися на законі і правильному сполученні форм і методів роботи, здійснюватися 3 дотриманням таких принципів: процесуальної самостійності слідчих і органів дізнання, невтручання в їхню процесуальну діяльність; вимог законності; самостійності співробітників оперативно-розшукових підрозділів, слідчих і спеціалістів у виборі засобів під час здійснення узгоджених заходів; поділу компетенції між учасниками взаємодії; нерозголошення учасниками взаємодії даних процесуальної, оперативно-розшукової й іншої діяльності; узгодженості планування і виконання дій учасниками взаємодії, наявності обміну інформацією тощо [3, с. 17].

Отже, аналіз наукової літератури із кримінально-процесуального права та криміналістики дозволяє виділити такі принципи використання спеціальних знань у процесі розслідування злочинів:

1. Принцип законності. Дотримання законності застосування спеціальних знань під час розслідування кримінального провадження означає, що вони здійснюються за умови точного дотримання вимог Конституції України й інших нормативно-правових актів, що становлять основу цієї діяльності, відповідно до їхньої юридичної сили. Порушення кримінально-процесуального законодавства під час використання спеціальних знань у розслідуванні кримінальних правопорушень недопустимо і призводить до відповідальності, встановленої законом.

2. Принцип незалежності особи, що володіє спеціальними знаннями, передбачає захист її від умов, що впливають на їі дослідження з боку слідчого (оперативного працівника, прокурора, суду), сторін та інших осіб, зацікавлених у результатах провадження, а також створення всіх умов, необхідних для самостійної творчої роботи. Принцип незалежності повинен надавати гарантії особі, яка володіє спеціальними знаннями, свободи у виборі того чи іншого методу виявлення, фіксації матеріальних слідів. Як зазначає А.М. Лазебний, складніша ситуація з гарантіями невтручання в законну діяльність спеціаліста. Як показує практика, найбільше піддаються цьому впливу ревізори та педагоги. Перші - тому що підпадають під вплив оперативних працівників і слідчих, які є штатними або позаштатними співробітниками органу, що веде кримінальне провадження, від яких може виходити самостійне джерело доказів, отримане у спрощеній стосовно експертизи формі, а другі - тому що зазвичай не мають належного уявлення про свою роль у процесі [4, с. 64].

3. Принцип об'єктивності, усебічності та повноти використання спеціальних знань означає неупереджену оцінку властивостей предметів і явищ на науковій і практичній основі, що виключає помилки, недопущення необгрунтованого судження. Об'єктивність використання спеціальних знань означає, що, по-перше, об'єкти вивчаються й описуються в тому вигляді, в якому вони були виявлені; 
по-друге, встановлені загальні й окремі ознаки, обставини, викладені письмово та реально відображають властивості об'єктів. Повнота використання спеціальних знань передбачає виявлення всіх об'єктів, незалежно від їх кількості, застосування всіх засобів криміналістичної техніки. Як показує практика, до переліку принципів варто додати принцип науковості, оскільки він допомагає постійно вдосконалювати методи та способи дослідження, упроваджувати нові рекомендації.

4. Принцип нерозголошення особою, яка застосовує спеціальні знання у процесі проведення слідчих (розшукових) дій, даних досудового слідства й оперативних відомостей. Таємниця слідства, як обгрунтовано зазначає А.М. Ларін, - це важлива умова виявлення доказів у тому вигляді, у якому вони є, без змін. Злочинці та пов'язані з ними особи не повинні знати про плани, джерела та межі поінформованості слідчого [5, с. 49].

5. Принцип неупередженості особи, яка застосовує спеціальні знання у процесі проведення слідчих (розшукових) дій. Принцип неупередженості використання спеціальних знань на досудовому слідстві означає, що особа або її родичі незаінтересовані в результатах кримінального провадження. Особа, запрошена як спеціаліст, не є потерпілим, цивільним позивачем, цивільним відповідачем або родичем кого-небудь із них, а також не є родичем слідчого, особи, яка провадила дізнання, або обвинуваченого тощо.

6. Принцип дотримання конституційних прав і свобод громадян, залучених у процес досудового слідства. У процесі використання спеціальних знань слідчий повинен особливо дбати про недоторканість законних прав і свобод громадян, незважаючи на їхнє процесуальне становище (обвинувачений, підозрюваний, захисник, потерпілий, цивільний позивач, цивільний відповідач, їхні представники, свідок, спеціаліст, експерт тощо).

7. Дотримання кожним учасником кримінального провадження у процесі використання спеціальних знань строго в межах своєї компетенції. Недопустимо змішування слідчої й іншої діяльності, за умови строгого дотримання підслідності. Дотримання цього принципу забезпечується чіткою правовою регламентацією діяльності слідчого і спеціаліста, контролем із боку керівників органів слідства й дізнання, прокурорським наглядом.

Висновки. Отже, Кримінальний процесуальний кодекс України окремо не визначає засади / принципи використання спеціальних знань у кримінальних провадженнях, однак містить вичерпний перелік загальних засад кримінального провадження. До правових засад використання спеціальних знань під час розслідування вбивств варто віднести такі, як: верховенство права, законності, рівності перед законом і судом, поваги до людської гідності, забезпечення права на свободу й особисту недоторканність, недоторканність житла чи іншого володіння особи, таємниця спілкування, невтручання у приватне життя, недоторканність права власності, законності, незалежності, об’єктивності і повноти дослідження. Сформульовані висновки є теоретичними категоріями, що становлять складову частину тих фундаментальних підстав для діяльності спеціалістів, експертів та працівників правоохоронних органів, що визначають зміст і напрями їхньої роботи. Правильне розуміння, тлумачення та дотримання наведених засад указаними 
суб'єктами є гарантією виконання завдань кримінального провадження, здійснення швидкого, повного, неупередженого й ефективного розслідування, забезпечення кримінального провадження належними доказами. Наведені положення є перспективним напрямом подальших наукових досліджень.

\section{Jimepamypa}

1. Бабаев В.К. Правовая система общества. Общая теория права : курс лекций. Нижний Новгород, 1993. $283 \mathrm{c}$.

2. Герасимов П.Ф. Взаимодействие органов предварительного следствия и дознания при расследовании особо опасных преступлений : автореф. дис. ... канд. юрид. наук. Свердловск, $1966.16 \mathrm{c}$.

3. Криміналістика : підручник : у 2-х т. / В.Ю. Шепітько та ін. Харків : Право, 2019, Т. 2. 328 с.

4. Лазебний А.М. Використання спеціальних знань при розслідуванні кримінальних правопорушень проти громадського порядку : дис. ... канд. юрид. наук: 12.00.09. Ірпінь, 2016. 235 с.

5. Ларин А.М. Работа следователя с доказательствами. Москва, 1966.149 с.

6. Махов В.Н. Использование знаний сведущих лиц при расследовании преступлений : монография. Москва : РУДН, 2000. 296 с.

7. Тертышник В.М., Слинько С.В. Тайное становится явным: взаимодействие следователя, оперативного работника и эксперта-криминалиста при раскрытии и расследовании преступлений : учебное пособие. Харьков : ИКФ «Гриф», 1997. 68 с.

\section{Анотація}

Марушев А. Д. Принципи застосування спеціальних знань у кримінальному провадженні. Стаття.

У статті висловлюється авторська позиція щодо визначення загальних засад / принципів використання спеціальних знань у процесі розслідування злочинів. Визначено й охарактеризовано правові й організаційні засади використання спеціальних знань під час розслідування злочинів. На наш погляд, принципи використання спеціальних знань визначеними суб'єктами кримінального провадження збігаються насамперед із нормами та принципами кримінально-процесуального законодавства, являють собою найважливіші й визначальні правові положення, на яких грунтується процес розслідування злочинів. Автором встановлюється, що використання спеціальних знань на досудовому слідстві здійснюється на підставі таких принципів: принципу законності використання спеціальних знань; принципу незалежності особи, що володіє спеціальними знаннями; принципу об'єктивності, усебічності та повноти використання спеціальних знань; принципу нерозголошення особою, яка застосовує спеціальні знання у процесі проведення слідчих (розшукових) дій, даних досудового слідства; принципу неупередженості особи, яка застосовує спеціальні знання у процесі проведення слідчих (розшукових) дій; принципу дотримання конституційних прав і свобод громадян, залучених у процес досудового слідства; принципу дотримання кожним учасником кримінального провадження у процесі використання спеціальних знань строго в межах своєї компетенції. Автором підкреслюється, що до загальних правових засад використання спеціальних знань під час розслідування злочинів варто віднести такі, як: верховенство права, законність, рівність перед законом і судом, повага до людської гідності, забезпечення права на свободу й особисту недоторканність, недоторканність житла чи іншого володіння особи, таємниця спілкування, невтручання у приватне життя, недоторканність права власності, законність, незалежність, об'єктивність і повнота дослідження. У статті відзначається, що правильне розуміння, тлумачення та дотримання наведених засад указаними суб'єктами є гарантією виконання завдань кримінального провадження, здійснення швидкого, повного, неупередженого й ефективного розслідування, забезпечення кримінального провадження належними доказами. Сформульовані у статті висновки є теоретичними категоріями, що становлять складову частину тих фундаментальних підстав діяльності спеціалістів, експертів та працівників правоохоронних органів, що визначають зміст та напрями їхньої діяльності у процесі розслідування злочинів.

Ключові слова: злочин, досудове слідство, принципи, слідчі (розшукові) дії, спеціальні знання. 


\section{Summary}

Marushev A. D. Principles of application of special knowledge in criminal proceedings. - Article.

The article expresses the author's position on the definition of general principles (principles) for the use of special knowledge in the investigation of crimes. identify and characterize the legal and organizational basis for the use of special knowledge in the investigation of crimes. In our opinion, the principles of using special knowledge by certain subjects of criminal proceedings coincide primarily with the norms and principles of criminal procedure legislation and are the most important and defining legal provisions on which the process of criminal investigation is based. The author establishes that the use of special knowledge in the pre-trial investigation is based on the following principles: the principle of legality of the use of special knowledge; the principle of independence of a person with special knowledge; the principle of objectivity, comprehensiveness and completeness of the use of special knowledge; the principle of non-disclosure by a person who applies special knowledge in the process of conducting investigative (search) actions of pre-trial investigation data; the principle of impartiality of a person who applies special knowledge in the process of conducting investigative (search) actions; the principle of observance of the constitutional rights and freedoms of citizens involved in the pre-trial investigation process; the principle of observance by each participant of criminal proceedings in the course of use of special knowledge strictly within the competence. The author emphasizes that the general legal basis for the use of special knowledge in the investigation of crimes should include the rule of law, legality, equality of law and court, respect for human dignity, the right to liberty and security of person, inviolability of home or other property, secrecy communication, privacy, inviolability of property rights, legality, independence, objectivity and completeness of the study. The article notes that the correct understanding, interpretation and observance of the above principles by these entities are guarantees of the tasks of criminal proceedings, the implementation of a prompt, complete, impartial and effective investigation and the provision of criminal proceedings with appropriate evidence. The conclusions formulated in the article are theoretical categories that are part of the fundamental foundations of the activities of specialists, experts and law enforcement officers, which determine the content and directions of their activities in the investigation of crimes.

Key words: crime, pre-trial investigation, principles, investigative (search) actions, special knowledge. 